\title{
A Review of Residential Segregation and Its Consequences in Nigeria
}

\author{
Maryam Salihu Muhammad1 \\ Rozilah Kasim² \\ David Martin ${ }^{3}$ \\ 1,2,3,Faculty of Technology Management \& Business, Universiti Tun Hussein Onn Malaysia, \\ 86400, Parit Raja, Batu Pahat, Johor, Malaysia \\ Email: maryam_salihu@yahoo.com
}

\section{Doi:10.5901/mjss.2015.v6n2s1p376}

\section{Abstract}

Residential segregation, the spatial separation of population sub-groups within a given geographical area, is a phenomenon which is prevalent in both developed and developing countries like Nigeria. This paper is aimed at reviewing residential segregation in Nigeria with specific reference to Northern Nigeria. The objectives of the paper are to review residential segregation from the pre-colonial to post-colonial era, and review its consequences in Nigeria. Prior to the colonial administration in Nigeria there existed no residential segregation based on race, ethnic or religious lines. The divide and rule policy of the British colonial administrators in Nigeria brought about residential segregation through the creation of 'Sabon Gari' settlements, which are occupied by the non-natives of Northern Nigeria. Residential segregation in Nigeria was reviewed in phases, that is, during the pre-colonial, colonial and the post-colonial era. In the final section of the paper the consequences of residential segregation in Nigeria, such as the socio-spatial division of households by income (high, medium and low density), inaccessibility of the poor to affordable housing, inadequate provision of infrastructure in the high density residential areas, and most importantly the cause of ethno-religious conflicts in across Nigeria, was discussed.

Keywords: Residential segregation, Nigeria, Northern Nigeria, Sabon Gari, Hausa

\section{Introduction}

Residential segregation is a widely researched urban phenomenon in both developed and developing countries. The research exercise has led to a prolific body of literature including the development of scientific measures of segregation (K'Akumu \& Olima, 2007). Residential segregation is a form of segregation that sorts population groups into various neighbourhood contexts and shapes the living environment and social space at the neighbourhood level. The residential neighbourhoods are often classified and segregated based on a variety of peculiarities. These include classification based on race/ethnicity, religion and economic/social status of individuals and groups within the population (Ifesanya \& Nwokoro, nd). The objectives of this paper are to review residential segregation from the pre-colonial to post-colonial era; and review its consequences in Nigeria, emphasis is however laid on Northern Nigeria. Prior to the colonial administration in Nigeria there existed no residential segregation based on race, ethnic or religious lines. The divide and rule policy of the British colonial administrators in Nigeria brought about residential segregation through the creation of 'Sabon Gari' settlements, which are occupied by the non-natives of Northern Nigeria.

In this paper a narrative review was made on literature, about residential segregation in Nigeria, which was sourced mainly from peer-reviewed articles and journals. The concept of residential segregation and an overview of residential segregation in West Africa are discussed first, then literature was reviewed on residential segregation in Nigeria starting from the pre-colonial era, to the colonial and the post-colonial era, and the consequences of residential segregation. The consequences of residential segregation in Nigeria has been to date the main cause of divide along ethnic and religious lines, and the major cause of incessant ethno-religious violence across Nigeria. In this paper, the authors reviewed literature that suggests that the colonial policies in Nigeria led to the emergence of residential segregation along socio-economic, ethnic and religious lines which have in turn affected the lives of the Nigerian people in many ways. 


\section{Concept of Residential Segregation}

Residential segregation was defined by Kemper (1998) as the spatial separation of population sub-groups within a given geographical area such as a large city. Such sub-groups can be formally defined in terms of age, occupation, income, birthplace, ethnic origin or other measures; or the sub-groups could be specified as social minorities distinguished from the dominant groups of power differentials. In another definition similar to that of Kemper, residential segregation is said to be the degree to which two or more groups live separately from one to another in different parts of the urban space (Aguilera \& Ugalde, 2007). While Aliyu, et al. (2012) opined that, it is the process where two or more communities that formerly lived together separate because of some factors. This they report could be because of either religious or ethnic reasons.

In the United States where the phenomenon is most prevalent, the African Americans are segregated in different neighbourhoods away from the whites. Thus, Cundiff \& Hudson (1999) defined residential segregation as the tendency for individuals with different racial backgrounds to inhabit different parts of metropolitan areas in greater concentrations. In the United States, segregation is often associated with the income level of the racial or ethnic group in question. Although many minority groups are segregated, the segregation levels of Blacks are significantly higher than those of other groups. Moreover, Blacks are more likely than other minorities to be hyper-segregated, i.e., to reside in mostly Black neighbourhoods that are surrounded by similar neighbourhoods in the centres of cities (Landrine \& Corral, 2009).

The segregation of whites from minorities persists in the US not because the minorities are segregated but because, according to Turner \& Fortuny (2009), of the interaction of barriers, fears and preferences. White preferences also play a key role, most whites and minorities would prefer to live in considerably more diverse neighbourhoods than they do (Krysan \& Farley 2002). The persistence of residential segregation in the United States is reported to be perpetuated by both private discrimination practices and through government policies. Leeuw et al (2007) stated that policies and practices of the United States government, as well as state and local governments, have helped to create highly segregated residential patterns across the United States. Many of the government programs and policies are said to concentrate poverty in communities of colour. Private housing treaties also discriminate against African Americans and Hispanics in renting or purchase of homes. Real estate agents restrict the entry of minority groups into white neighbourhoods by steering and restrictive covenants (Sugrue, 2008, Greenstein, Sabatini \& Smolka, 2000).

The African Americans are usually concentrated in inner city enclaves and public housing, and regardless of their socioeconomic status, they are less likely to move into areas that are more affluent. According to Turner \& Fenderson (2006), the link between neighbourhood racial and income, composition remains the starkest for African Americans; neighbourhoods where blacks constitute the predominant minority group are the most likely to have high poverty rates and the least likely to be occupied exclusively by affluent households. However, contrary to what obtains in the United States and other parts of Europe, the situation of minorities in London differs. In the U.S., minorities are outpaced in suburbanisation by the white population, in London research has revealed that there is continuing suburbanisation of ethnic minorities and rising home ownership, with a decline in White homeownership in suburban London. The minorities in London were also shown to be concentrated in social and private rented housing in both inner and outer London (Hamnett \& Butler, 2009).

In Malaysia, according to Thong (1978) the colonial administrators isolated themselves from the Asians by residing on the hilly west bank of the river Klang which have presently become the residence of the upper echelons of society. In furtherance of this, the colonial policies have led to residential segregation among the lower income Malays and Chinese on the east bank, thus leading to the perpetuation of Chinatown and Malay settlements. This brings to light residential segregation along ethnic and income lines. In a related report by Ramli \& Jamaludin (2012), the British colonial "divide and rule" policy was said to be the reason why, the Malays, the Chinese and the Indians were never integrated as one community. The policy geographically segregated these individual communities into three different areas; the Chinese were concentrated in urban areas, the Malays were mainly in rural areas and the Indians were in rubber plantations.

In Africa, residential segregation cannot be discussed without referring to the colonial period. In West Africa, the British colonialist separated their quarters from those of the natives. Edewor (2011) reported that prior to the colonial era there was co-habitation in Nigerian cities among people of various nations, social and ethnic origins. He opined however that the British put an end to that pattern of residence by imposing spatial, legal and psychological boundaries between social, ethnic, or racial categories to enforce a clear division between so-called races and ethnic groups to make these categories visible in everyday life. In a report by K'Akumu \& Olima (2007) residential segregation in settler colonies like Kenya, Zimbabwe and South Africa originated as racial segregation policies of the state. Residential segregation of the colonial regimes was instituted and implemented through land policy thereby giving it a spatial dimension; this gave rise 
to segregation by the state. Several legislations were passed in South Africa but the Group Areas Act of 1950 was reported to be the most systematically applied. It gave the government power to demarcate where each racial group could live and own property and control all property transactions between different racial groups [see South African History Online (SAHO), nd].

\section{Residential Segregation in Colonial West Africa}

The practice of housing segregation in British West Africa was not part of the general pattern of racial segregation practiced in other British colonies. Gale (1980) reported that the system practised in West Africa was mainly as a result of the outbreak of plague and yellow fever epidemics in 1908 and 1910 which necessitated the medical authorities to recommend residential segregation as essential to safeguarding the lives of the European officials. The policy of segregation was the most resented features of the colonial rule and the Africans disapproved the heavy investment of their tax money in providing reservations and bungalows for the Europeans, the removal of well-to-do Africans from their large homes, and the absolute neglect of the local towns.

Segregation had not been practised in West Africa in the $19^{\text {th }}$ century although it was the practise in British colonial India where the British lived separately from the Muslim and Hindu population. People on the coastal areas of West Africa mingled easily with the British since the $15^{\text {th }}$ century. The discovery of the mosquito as the vector for malaria in 1897 led to the recommendation of segregation as a preventive measure. In 1898 the Royal Society through its Malaria Investigating Committee recommended that the Europeans should be segregated form the natives because it was viewed as the only way of preventing malaria. They were further reported to have said that the native children were the primary reserves for malaria, and since there were limited resources at the disposal of the Europeans to prevent malaria, the most feasible option was to segregate Europeans from the natives.

Many governors at that time realised the danger of such policy and they were able to enforce other health measures until 1910. Governor William MacGregor of Lagos opposed such policy on health grounds. Being a medical doctor and a British health official, he advocated that the Europeans remain among the natives (believing that with separation on colour bias the source of contamination will remain) and employ ways of eradicating the disease (and mosquitoes) permanently. He also opposed it on humanitarian grounds believing that it will lead to social problems and he wanted no racial problems in Lagos. Macgregor's health program involved the eradication of mosquitoes, free distribution of quinine and introduction of hygiene and sanitation courses in local schools.

Although the European death rate was reported to have decreased around 1910 with the adoption the health program, segregation schemes were still adopted. The Hill Station above Freetown was completed between 1900 and 1910 in spite resistance from two past governors on the movement to the station. The first event that necessitated the adoption of segregation was the outbreak of the plague in 1908 in Accra, Ghana. The disease was said to have claimed the lives of over six million people in India between 1898 and 1907. The principal medical officers of the British West African colonies called for the segregation of the Europeans from the natives and recommended that 400 yards distance from native towns be adopted. However, the event that absolutely made segregation enforceable was the outbreak of the yellow fever in Sekondi, which claimed the lives of nine Europeans.

The most conflict over the adoption of segregation between the European officials and medical officers were those over Gambia, the Gold Coast and Northern Nigeria. The adoption of the scheme in Gambia began in 1913 and it resulted in the removal of well-to-do Africans from their Clifton-Marina Road area in Bathurst. They were relocated to the land reclaimed from the edge of the large un-healthy Half-Die swamp. In the Gold Coast the segregated areas selected were Kumasi, Sekondi, Dunkwa, Tarkwa, Axim, Cape Coast, and Winneba. The officials had by 1914 built enough bungalows for the occupation. All these projects were at the expense of the natives. Although the then governor of the Gold Coast Sir Hugh Clifford strongly opposed segregation on social grounds and argued that it was unfair to lavishly spend the tax money-which was largely collected from the natives-on the European officials. He was however not successful in his plight.

In Northern Nigeria the medical officers in that region were reported to be more conservative, the type that would want to live in separate quarters from the natives, and the natives had no prior contact with the Europeans. There was no social contact between the two groups thus a formal and distant relationship developed between them The Muslims were particularly said to be more pleased with the Europeans living separately because they feared that they may adulterate their religion. Segregation in this region and the Northern part of the Gold Coast were said to be less offensive than those of Freetown and Lagos.

The medical officers in Northern Nigeria wanted Africans that were non-natives of the land to live in their own separate areas so that they do not enjoy a commercial advantage over the Europeans in the area. This act of the officials 
was what led to the realisation of new towns popularly known as the Sabon Gari. In 1911 a standard plan was developed in Nigeria having three categories of towns which contains: European cantonments or stations which was exclusive of any Africans, alien towns near the cantonment which would contain non-native traders, missionaries, and other immigrants, and regular native towns. The European stations were to be 'garden cities' having a European standard of living. Minna was one alien of the towns. These events are the genesis of the present pattern of residential settlements in Nigeria and other African countries.

\section{Residential Segregation in Pre-Colonial Nigeria}

The region of Nigeria was predominantly rural in the pre-colonial era. This is not, however, to suggest the absence of cities in the region at that period. Indeed, such Nigerian cities as Ibadan and Kano were among the largest cities in the continent of Africa at that time. Many of the cities had long been in existence before the advent of colonialism. The city of Kano, for example, had existed for at least 900 years before the British colonized Nigeria. Similarly, Benin City has a long history (Edewor, 2011). Nigeria has a long history of urban development particularly in the northern and southern parts where a substantial number of the cities existed centuries before the advent of colonial rule.

Nigeria provides diverse examples of historical urban development. A useful distinction that could enhance our understanding is the classification of the cities into indigenous and non-indigenous (Edewor, 2011). This distinction refers to the development or emergence of a city relative to the colonial period. By implication, indigenous cities are those that originated prior to the period of the British colonial rule while those planned and constructed during the colonial period (1900-1960) are non-indigenous. Kano is an indigenous city. It traces its origin to the era much before the arrival of the British, approximately 1000 A.D. and it is among the oldest continuously occupied cities in the whole of sub-Saharan Africa. However, it was not until the 14th century that it developed its Islamic character, after the coming of Islam. With the consolidation of Islam, Kano became a major terminus of trans-Saharan trade and this supplemented its role as a centre of Islamic Teaching and Education. Like other northern savannah cities, Kano grew within city walls. The main market, the government buildings and the central mosque were located at the centre. The houses of the rich and powerful then clustered around them. Found away from this core were smaller markets and denser housing, and with the little markets at the gate of the city. Groups of craft manufacturers as blacksmiths, cloth dyers, weavers, potters and the like were organised in to special quarters. These crafts were often family-based and they were inherited. Thus, residential differentiation was based on crafts and some degree of occupational specialization.

The residential pattern that existed in pre-colonial Nigerian cities was altered by the advent of British colonialism. Prior to that time, there was a form of cohabitation among people of various nationals, social and ethnic origins. However, the British resolved to put an end to this residential pattern. Spatial, legal and psychological boundaries between social, ethnic, or racial categories were imposed to enforce a clear division between so-called races and ethnic groups to make these categories visible in everyday life (Edewor, 2011).

\section{Residential Segregation in Colonial Nigeria}

The urban political structure of the colonial era was completely different from that of the pre-colonial era. Be it in the indigenous cities like Kano, or in the non-indigenous or new ones like Jos, residential segregation was the norm and it was based on religion, ethnic origin and race. The Sabon Gari system in northern emirate cities was the epitome of this British-imposed policy, based on the principle of divide and rule. For example, the settlement known as Sabon Gari (which means 'new town' in Hausa language) in northern Nigeria was first established in Kano around 1911. At this time, Kano was already an Islamic city and it was populated by the Kanawa (the indigenous Kano people) who vehemently resisted the British colonisation in 1903. The colonial authorities became keenly aware of the need to respect the sanctity of Islam in Kano. Consequently, the Sabon Gari settlement was founded [or the dominantly Christian southern Nigerian migrants who trooped into the city. As the Kanawa distanced themselves from the colonial authorities most especially on religious grounds, more southern Nigerians migrated into Kano to serve the whites. This way, the image of Sabon Gari as a settlement of 'strangers' was consolidated (Edewor, 2011; Uchendu, 2010).

Interestingly, Albert (1996) commented that Kano is segregated into sub-communities, these are, Birni for the indigenes; the European quarters for the colonial administrators and other white people; the Sabon Gari for the southern Nigerians and other West African immigrants; Tudun Wada for the Muslim non-native northerners who work for the whites and; Gwagwarwa for the non-Muslim northern Nigerians.

It should be emphasized that the colonial pattern of residential segregation in these cities was not chosen by the Nigerians themselves. Rather, it was deliberately established and enforced by the colonial power. In Zaria, for example, 
during the first decades of colonialism, heterogeneous population of migrants sprang up outside the city walls, on the present site of Sabon Gari. It was populated by people from different parts of Nigeria, who had come to Zaria as a result of the railway and cotton ginnery. Some of the indigenes of Zaria even came and settled there. However, by early 1920s the British began to entertain some fears. They envisaged that this community of diverse people might create a situation that would not be in their (the British) interest. They felt threatened by the existence of this heterogeneous population domiciled in Sabon Gari. Consequently, they issued an order stating that Muslims must not live in Sabon Gari. They also enforced the regulation that non-indigenes could not live in Zaria old city. The result was that the Muslims were removed from Sabon Gari while all non-Muslims were removed from the Zaria old city. At the same time, the British reserved for themselves the Government Reservation Area (G R. A). These G.R.A.'s still exist in our major towns like Lagos, Kaduna, Jos, Bauchi, Ibadan etc (Ademiluyi \& Aluko-Arowolo, 2009). Eventually, the residential pattern of the Zaria metropolitan area came to be a totally segregated one, dividing the indigenes from non-indigenes, the Christians from Muslims, and the Europeans from Africans. This was a completely different picture from what obtained in the pre-colonial period, where everyone, regardless of ethnic origin had settled within the city walls (Edewor, 2011).

\section{Residential Segregation in Post-Colonial Nigeria}

The establishment of the Sabon Garis (new towns) and Tudun Wadas during the colonial period in Kano, Zaria and other parts of the north was reported to be done with intent of avoiding direct contact with the indigenous people based on the policy of indirect rule and residential segregation. These new settlements were situated adjacent to the traditional cities for the non-natives (Dung-Gwom, 2008).

Albert (1996) reported that many types of segregated sub-communities are now found in Nigerian cities. The segregation in these cities is religiously motivated, ethnically motivated, professionally motivated and economically motivated. The Sabon Gari settlements are now found not only in the northern Nigerian cities but also in the southern Nigerian cities and their peculiarity derives from their unique demographic composition, social orientation and religious characteristics. The Sabon Gari settlements in the Hausa-Fulani dominated northern Nigerian cities are inhabited by southern Nigerian migrants while those in the Yoruba dominated south-western Nigeria are domiciled by the HausaFulani settlers. Its abridged version, "Sabo", became popularized in south-western Nigeria and they are found in such Yoruba cities as Ibadan, ljebu-Ode and Sagamu, -these Hausa settlements in Yoruba land according to Blair (1966) are called Zongos. In Igbo dominated eastern Nigeria, the Hausa-Fulani settle in the 'Abakpa Quarters'. These are, however, stranger settlements established by the strangers themselves through their continuous aggregation in given locations within the urban system. They are, however, patterned after the Sabon Gari settlements, which were established during the colonial era (Albert, 1996; and Osaghae \& Suberu, 2005). Odoemene (1990) also reported that the Hausa migrant enclaves in Enugu carry names such as Garki, Ama Awusa, and Hausa Quarters (Ogbe Hausa as reported by Uchendu, 2010); these enclaves exist in the midst of their host communities and have been reported to be less radical than those in the core Hausalands.

Bearing in mind the general aims and the specific objectives of the British colonial administration in West Africa, Asike (nd) and Nwaka (1999) opined that the British administration was not interested in developing the cities in a way that would realise and maximise their positive role in the overall development of the region. Urban planning in the region was merely to provide enclaves or escapes where temporary migrants from the homelands could be posted to organize increased productivity. With such a limited objective and a narrowly defined role for the region, the colonial planning approach was simple. Its strategy was basically to regulate and control the physical growth of the cities within a graded framework. Land use, zoning and building bylaws were designed to minimise costs and to separate the colonisers from the colonised. Therefore, the traditional (older) sections of the towns were simply ignored and contained, while serious planning efforts were concentrated on the establishment of new areas. According to Nwaka (2005a) planning and housing were used as instruments of segregation and social policy - to ensure that the small community of Europeans was protected in segregated high quality residential reservations.

Blair (1966) reported that in Africa as people ascended to higher ranks of power they took up residence in formerly occupied European residential areas, or in isolated medium housing estates. As the African elites crossed the ethnicclass line they foreshadow the egalitarian residential pattern that was typical of traditional local African communities where people of different class and occupation resided on one street, and herald the rise of one-class neighbourhoods which were common in the Western nations. He went further to say that the attainment of new status positions was expressed by dissociation from the traditional group and association with another group in better surroundings. The African elites created and separated by residence as well as income, education and standard of living from the masses of people. Such exodus affected the community by depriving it of leadership and taxable income. 
The segregation system imposed by the British colonialists is still present in the modern or post-colonial Nigeria. These laws were reported to be inherited without much thinking on the part of the government (Nwaka, 1999, 2005a). The result of the British inherited planning policies through the Town Planning Laws, and the Nigerian property market led to the development of the three distinctive residential neighbourhood types in almost all Nigerian cities. These neighbourhoods are referred to as the high, medium and low density residential areas (Asiyanbola, 2003) and government reservation area for top government officials and successful business people with varying housing standard and amenities based on demand and supply forces (Oyebanji, 2011).

\section{Consequences of Residential Segregation}

Residential segregation, in both ethnic and income terms, are considered an undesirable phenomenon which impacts the opportunities, prospects and quality of life of the residents, especially in urban areas. In general, terms, selective migration and segregation are expected to disconnect poor residents from mainstream society (Kleinhans, Van der Land \& Doff, 2010). The spread of impoverished urban areas is said to lead to the physical and social deterioration of neighbourhoods. High residential turnover and the increased concentration of poverty resulted in housing disinvestment and deteriorated physical conditions, a reduction in the capacity of formal and informal institutions to maintain public order. It also leads to a decline in the ability of informal networks to circulate information (e.g., about employment opportunities and health resources) and to promote healthy behaviours and positive life choices (Anderson et al., 2003; Ellen \&Turner, 1997; MacDonald et al., 2005; Greenstein, Sabatini \& Smolka, 2000; Bayer, McMillan \& Reuben, 2001; Edwards, 1970; and Surge, 2008). While Leeuw et al. (2007) posited that racial discrimination and segregation in public housing affects women to a greater degree than men.

Other authors such as Sugrue (2008) reported that persistent racial segregation has created racial homogeneity in school districts and racial polarisation of politics. Many segregated neighbourhoods are served by failing public schools with high dropout rates, low instructional quality, and poor test scores (O'Regan \& Quigley, 1996). Turner and Fortuny (2009) reported that higher levels of segregation were closely related to high level of school dropout rates among blacks, lower employment rates and a wider gap between the black and whites (see Cutler \& Glaeser, 1997). A study by NuruJetter \& LaVeist (2011) showed that there was a positive relationship between income inequality and mortality rate among poor African-Americans. Racially segregated areas, particularly lower income areas, are associated with lower quality schools, fewer employment and economic opportunities, exposure to crime, substandard housing, exposure to toxins and pollutants, and isolation from broader social networks, all of which have been associated with poorer health.

The advent of residential segregation has been the main cause of the development of squatter and informal settlements, and slums in many parts of Africa (SAHO, nd; Dung-Gwom, 2008). For instance in Cape Town, South Africa, the shanty and informal settlements are because of the segregation of Africans and non-white people from the white neighbourhoods. The inability of the government to adequately provide housing for the displaced African population led to the people taking up residence in outside areas of the white settlements (see SAHO, nd). Similarly, in Nairobi, Kenya, the economic segregation of blacks has made access to land and housing difficult because they belong to the lowest income group. These low-income groups are confined to informal settlements along the Eastland areas and around high-income residential areas, thereby enabling the inhabitants to work as agricultural labourers or domestic servants, while others were employed in industrial and commercial concerns (K'Akumu and Olima, 2007).

K'Akumu and Olima (2007) stated these squatter and informal settlements are the consequence of the colonial capitalist development imposed by the British who alienated the local people from control over their land in order to provide surplus labour for the settler farms and emerging urban centres. They further stated that the combination of racial and income residential segregation has resulted into systematic and uneven spatial distribution of public services including schools, access to transportation, health care, and water and sanitation. In the low-income areas, that the lower income group, that is, Africans live is characterised by rented accommodation, poor nutrition, expensive food and cooking fuel, high level of disease, high infant mortality, poor family planning and teenage pregnancy, poor health care, and low school enrolment. In addition, persons residing in neighbourhoods with high concentrations of low-income and minority households face higher crime rates. These neighbourhoods also have higher rates of unemployment, and lack of access to job networks and transportation, which hinders households from fully accessing employment opportunities.

\section{Consequences of Residential Segregation in Nigeria}

The consequences of residential segregation in Nigeria have been highlighted by several authors. In Nigeria, DungGwom (2008) posited that the development of peri-urban settlements were stimulated during the colonial period as new 
towns (sabon garis and tudun wadas) were situated adjacent to traditional cities (to avoid direct contact with the indigenous people based on the policy of indirect rule and residential segregation), and government policies of locating institutions and industries away from cities (for example Ahmadu Bello University at Samaru, Zaria, the airport in Jos and recently in Gombe, etc) have reinforced the processes of spatial de-concentration and peri-urban growth.

Asiyanbola (2003) reported that the post-colonial era witnessed the socio-spatial division of households by income (high, medium and low density), because of the adoption of the modern town planning. This division of housing into three groups led to a distinction in the quality of houses (Edewor, 2011) with the high density areas being the most deplorable in terms of urban safety, security and neighbourhood conditions (Asiyanbola, 2003) and women were found to be most distressed psychologically because of neighbourhood and housing conditions in these segregated areas.

According to Nwaka (1999) residential segregation inhibits the access of the poor to affordable housing and tenure security, the inadequate provision of water, sanitation and waste management which have led to the spread of disease such as cholera, typhoid, diarrhoea and malaria among others. While these problems are most evident in poor neighbourhoods, Ademiluyi \& Aluko-Arowolo (2009) reported that the distribution of health care facilities is lop-sided with the affluent people in Nigeria receiving the lion's share.

Edewor (2011) asserted that the residential segregation created by the British colonial administration in Nigeria led to the emergence of conflict between the separate communities (that is natives and non-natives, Muslims and Christians). These conflicts are not far-fetched from the negative stereo-types about the Sabon Gari settlements. Albert (1996) reported that the sabon gari settlement in Kano became points of prostitution and sales of alcohol drinks, a development which gave the area a stigma of religious misfits. The negative stereo-types about the sabon gari and its inhabitants have been the cause of the incessant ethno-religious conflicts in Kano, and indeed many states in the country. These conflicts have in turn affected the sales and rental value of residential properties in the affected areas for instance in Jos (see Dung-Gwom, 2008, 2009; Aliyu et al., 2012).

\section{Conclusion}

In this paper residential segregation in Nigeria was reviewed from the pre-colonial, colonial to the post-colonial era, and finally the consequences of residential segregastion was reviewed. The discussion on residential segregation in Nigeria has revealed that prior to the British colonial rule there existed no residential differentiation based on ethnicity or race, people of diverse tribes and nationals cohabited in the north. The creation of residential segregation by the colonial administrators brought about the emergence of the sabon gari and tudun wada settlements (new towns) which housed the southern Nigerians living in the north. Several scholars have reported that the residential segregation by ethnic and religious grounds in Nigeria is a factor which has led to the present inaccessibility of the poor to affordable housing, security, inadequate provision of infrastructure in the high density residential areas, and most importantly the cause of ethno-religious conflicts in across Nigeria.

\section{References}

Ademiluyi, I. A. \& Aluko-Arowolo, S. O. (2009). Infrastructural distribution of healthcare services in Nigeria: An overview. Journal of Geography and Regional Planning Vol. 2(5), pp. 104-110, May, 2009. Retrieved on 31/12/2012 from http://www. academicjournals.orgjgrppdfPDF\%202009MayAdemiluyi\%20and\%20Aluko-Arowolo.pdf

Aguilera, A. \& Ugalde, E. (2007). A spatially extended model for residential segregation: Research Article. Discrete Dynamics in Nature and Society Volume 2007. Retrieved on 05/02/2013 from www.hindawi.com/journals/ddns/2007/048589/abs/

Albert, I. O. (1996). Ethnic residential segregation in Kano, Nigeria and its antecedents: African Study Monographs, 17(2):85-100. Retrieved on 18/12/2012 from http://jambo.africa.kyotou.ac.jpkirokuasm_normalabstracts.pdf

Aliyu, A. A., Kasim, B. R, Martin, D, Mohd, L. M. D., \& Ali, M. A. (2012). Implication of intangible location attributes on residential segregation in Jos, Nigeria; Journal of Sustainable Development; Vol. 5, No. 11; Canadian Center of Science and Education; Retrieved on 17/12/2012 from www.ccsenet.orgjournalindex.phpjsdarticledownload...14163

Anderson, L.M., St.Charles, J., Fullilove, M.T., Scrimshaw, S.C., Fielding, J.E., \& Normand, J., (2003). Providing affordable family housing and reducing residential segregation by income: A systematic review. American Journal of Preventive Medicine. Retrieved on 18/12/2012 from http://www.thecommunityguide.orgsocialsoc-AJPM-evrev-housing.pdf

Asike, J. I. (nd). The city in modern Nigeria: A force in rapid social change. Retrieved on 18/12/2012 from http://www.crvp.org/book/ Series02/II-3/chapter_iv.htm

Asiyanbola, A. R. (2003). Gender, residential segregation, psychological well-being and involvement in sustainable urban safety and security management in Ibadan city, Nigeria: A preliminary survey. Sustainable Planning and Development. Retrieved on 02/02/2013 from http://library.witpress.compagesPaperInfo.aspPaperl

Bayer, P., McMillan, R. \& Rueben, K. (2001). The causes and consequences of residential segregation: An equilibrium analysis of 
neighbourhood sorting. Retrieved on 17/12/2012 from http://www.econ.yale.eduseminarsapmicroam01bayer-011004.pdf

Blair, T. L. V. (1966). Man's quest shelter in urbanising Africa. Town and Country Planning, Keele. Retrieved on 30/12/2012 from http://chronicleworld.orgcollectedarticles1966\%20Mans\%20quest\%20shelter.pdf

Cundiff, R. E. \& Hudson, D. (1999). Using geographic information systems to measure segregation in U.S. metropolitan areas. Retrieved on 17/12/2012 from http://www.utexas.edu/depts/grg/hudson/grg394k/studentprojects/cundiff/cundiff.html

Cutler, D. M. \& Glaeser, E. L. (1997). Are ghettos good or bad? National Bereau of Economic Research (NBER) Working Paper Series, Working Paper No.5163. retrieved on 16/02/2013 from http://www.nber.org/papers/w5163.pdf?new_window=1

Dung-Gwom, J. Y. (2008). The nature of peri-urban developments in Jos, Nigeria: Proceedings of the World Congress on Housing: National Housing Programme-New Vision, November 03-07, 2008, Kolkata, India. Retrieved on 18/12/2012 from http://dspace.unijos.edu.ng/.../Nature\%20of\%20Peri-

Dung-Gwom, J. Y. \& Rikko, L. S. (2009). Urban violence and emerging land and housing markets in Jos, Nigeria: Proceedings of the ISA Housing Conference, Glasgow, 1-4 September 2009. Retrieved on 19/12/2012 from http://www.cppr.ac.ukmediamedia_ 129777_en.pdf

Edewor, P. A. (2011). Residential segregation in Nigerian cities in Sandhu, R. S. \& Sandhu, J. (Ed) Globalizing cities. Inequality and segregation in developing countries (pp 29-42) http://eprints.covenantuniversity.edu.ng5951Residential_Segregation_in_ Nigerian_Cities.pdf

Edwards, O. L. (1970). Patterns of residential segregation within a metropolitan ghetto: Demography volume 7, number 2. Retrieved on 10/01/2013 from http://link.springer.comcontentpdf10.2307\%2F2060410

Ellen, I. G. \& Turner, M. A. (1997). Does neighbourhood matter? Assessing recent evidence. Housing Policy Debate, volume 8, issue 4, pp 833; Fannie Mae Foundation. Retrieved on 05/02/2013 from http://content.knowledgeplex.org/kp2/kp/.../hpd_0804_ellen.pdf

Gale, T. S. (1980.). Segregation in British West Africa. Cahiers d'Etudes africaines, 80, XX-4, pp.495-507. Retrieved on 30/12/2012 from http://www.webafriqa.netlibraryfrancaiseceasegregation_british_west_africa.pdf

Greenstein, R., Sabatini. F. \& Smolka, M. (2000). Urban Spatial Segregation: Forces, Consequences, and Policy Responses. Newsletter of the Lincoln Institute of Land Policy. Retrieved on 13/01/2013 from http://www.lincolninst.edu/pubs/276_Urban-SpatialSegregation--Forces--Consequences--and-Policy-Responses

Hamnett, C. \& Butler, T. (2009). The Changing Ethnic Structure of Housing Tenures in London, 1991-2001. Urban Studies 47(1) 55-74. Retrieved on 17/02/2013 from http://usj.sagepub.com/content/47/1/55.refs.html

Ifesanya, K., \& Nwokoro, I. (n.d.). Transforming social exclusion to benefit in the slum areas of the Global South through neighbourhood identity: lessons from Ajegunle slum in Lagos, Nigeria. socialspacejournal.eu, 1-23. Retrieved on 19/12/2012 from http://socialspacejournal.euCzwarty\%20numerlfesanya,\%20Nwonkoro\%20-\%20Transforming\%20social\%20exclousion.pdf

K'Akumu, O. A \& Olima, W. H. A. (2007). The dynamics and implications of residential segregation in Nairobi: Habitat International 31 (87-99). Retrieved on 21/12/2012 from www.korogocho.orgenglishindex. phpoption=com...24...pdf

Kemper, F. J. (1998). Residential segregation and housing in Berlin: changes since unification. Geojournal 46: 17-28,1998. Retrieved on 058/02/2013 form http://link.springer.com/article/10.1023\%2FA\%3A1006902400293?LI=true

Kleinhans, R., Van der Land, M. \& Doff, W. (2010). Dealing with living in poor neighbourhoods. J Hous and the Built Environ (2010) 25:381-389. Retrieved on 02/02/2013 from http://link.springer.comcontentpdf10.1007\%2Fs10901-010-9194-5

Krysan, M. \& Farley, R. (2002). The Residential Preferences of Blacks: Do They Explain Persistent Segregation? Social Forces Volume 80, Issue 3, pp. 937-980. Retrieved on 17/02/2013 from http://sf.oxfordjournals.org/content/80/3/937.short

Landrine, H. \& Corral, I. (2009). Separate and unequal: Residential segregation and black health disparities. Ethnicity \& Disease, Volume 19, Spring 2009 (pp179-183). Retrieved on 19/12/2012 from http://www.ishib.orgjournal19-2ethn-19-02-179.pdf

Leeuw, M. B. de, Whyte, M. K., Ho, D., Meza, C., \& Karteron, A. (2007). Residential segregation and housing discrimination in the United States: Violations of the International Convention on the Elimination of All Forms of Racial Discrimination. A Response to the 2007 Periodic Report of the United States of America. Retrieved on 11/01/2013 from http://www2.ohchr.orgenglishbodiescer ddocsngosusaUSHRN27.pdf

MacDonald, R, Shildrick, T, Webster, C. \& Simpson, D. (2005). Growing up in poor neighbourhoods: The significance of class and place in the extended transitions of 'socially excluded' young adults: Sociology, 39 (5), pp.873-891. Retrieved on 05/02/2013 from http://dx.doi.org/10.1177/0038038505058370

Nuru-Jeter, A. M. \& LaVeist, T. A. (2011). Racial segregation, income inequality, and mortality in US Metropolitan Areas. Journal of Urban Health: Bulletin of the New York Academy of Medicine, Vol. 88, No. 2Retrieved on 10/01/2013 from http:/llink.springer. comcontentpdf10.1007\%2Fs11524-010-9524-7

Nwaka, G. I. (1999). The urban poor, the informal city and environmental health policy in Nigeria. Retrieved on 19/12/2012 from http://www.engagingcommunities2005.orgabstractsNwaka-Geoffrey-final.pdf

Nwaka, G. (2005a). Using Indigenous Knowledge to strengthen Local Governance and to counter Urban Inequality in Nigeria, 1, 383390. Retrieved on 19/12/2012 from http://www.realcorp.at/archive/CORP2005_NWAKA.pdf

Odoemene, A. (1990). The historical dynamics of migration into Enugu city, Southeastern Nigeria, 1915-1990. irmgard-coninxstiftung.de. Retrieved 18/01/2013 from www.irmgard-coninx-stiftung.de/fileadmin/user.../Odoemene.pdf

O'Regan, K. M. \& Quigley, J. M.(1998). Spatial effects upon employment outcomes: The Case of New Jersey teenagers. UC Berkeley Working Paper IBER-CalBerk E96-247. Retrieved on 18/02/2013 from http://ssrn.com/abstract=97788

Osaghae, E. E. \& Suberu, R. T. (2005). A history of identities, violence, and stability in Nigeria. CRISE Working Paper No. 6, Centre for Research on Inequality, Human Security and Ethnicity, CRISE. Retrieved 31/12/2013 from http://www.dfid.gov.ukr4dpdfout 
putsinequalitywp6.pdf

Oyebanji, A. O., Akintoye, A. \& Liyanage, C. L. (2011). Public-Private Partnerships Approach: A panacea to urban housing inequalities in developing countries- A case study of Nigeria in Akintoye, A., Liyanage, C. \& Renukappa, S. (Ed) proceedings of CIB TG72 /ARCOM Doctoral Research Workshop. University of Central Lancashire, United Kingdom. Retrieved on 19/12/2012 from http://clok.uclan.ac.uk29861CIBTG72-ARCOM_Doctoral_Proceedings .pdf\#page=71

Ramli, M. A. \& Jamaludin, M. A. (2012). Interaction of Plural Society in Malaysia: Diatribe or Dialogue. World Journal of Islamic History and Civilization, 2 (1): 53-57. Retrieved on 21/01/2013 from http://idosi.orgwjihcwjihc2\%281\%29127.pdf

SAHO (nd). Cape Town: the segregated city. South African History Online: Towards A People's History. Retrieved on 3/02/2013 from http://www.sahistory.org.za/places/cape-town

Sugrue, T. J. (2008). The unfinished history of racial segregation.

Thong, L. B. (1978). Attitudinal correlates in residential location: A case study in Malaysia. South East Asian Studies, Vol. 16 No.2 (pp 159-174). Retrieved on 26/01/2013 from http://repository.kulib.kyotou.ac.jpdspacebitstream2433559171KJ00000133320.pdf

Turner, M. A \& Fenderson, J. (2006). Understanding diverse neighbourhoods in an era of demographic change. The Urban Institute. Retrieved on 16/02/2013 from http://www.urbaninstitute.org/UploadedPDF/411358_diverse_neighborhoods.pdf

Turner, M. A., \& Fortuny, K. (2009). Residential segregation and low-income working families: Low income working families. The urban institute, (February). Retrieved on 18/12/2012 from http://www.urban.orgUploadedPDF411845_residential_segregation_liwf.pdf

Uchendu, E. (2010). Religious conflicts in Nigeria implications for socioeconomic and psychological perceptions of Muslims. Retrieved on 17/12/2012 from www.egodiuchendu.com/index.php?...religious-conflicts-in-nigeria-impl... 